\title{
A comparative study of genome organization and inferences for the systematics of two large bushcricket genera of the tribe Barbitistini (Orthoptera: Tettigoniidae: Phaneropterinae)
}

\author{
Beata Grzywacz ${ }^{1 *}$, Dragan P Chobanov², Anna Maryańska-Nadachowska', Tatyana V Karamysheva ${ }^{3}$,
} Klaus-Gerhard Heller ${ }^{4}$ and Elżbieta Warchałowska-Śliwa ${ }^{1}$

\begin{abstract}
Background: Poecilimon and Isophya are the largest genera of the tribe Barbitistini and among the most systematically complicated and evolutionarily intriguing groups of Palearctic tettigoniids. We examined the genomic organization of 79 taxa with a stable chromosome number using classical (C-banding, silver and fluorochrome staining) and molecular (fluorescence in situ hybridization with 185 rDNA and (TTAGG) $n$ telomeric probes) cytogenetic techniques. These tools were employed to establish genetic organization and differences or similarities between genera or species within the same genus and determine if cytogenetic markers can be used for identifying some taxonomic groups of species.

Results: Differences between the karyotypes of the studied genera include some general changes in the morphology of the X chromosome in Isophya (in contrast to Poecilimon). The number of major rDNA clusters per haploid genome divided Poecilimon into two main almost equal groups (with either one or two clusters), while two rDNA clusters predominated in Isophya. In both genera, rDNA loci were preferentially located in the paracentromeric region of the autosomes and rarely in the sex chromosomes. Our results demonstrate a coincidence between the location of rDNA loci and active NORs and GC-rich heterochromatin regions. The C/DAPI/ $\mathrm{CMA}_{3}$ bands observed in most Poecilimon chromosomes suggest the presence of more families of repetitive DNA sequences as compared to the heterochromatin patterns in Isophya.

Conclusions: The results show both differences and similarities in genome organization among species of the same genus and between genera. Previous views on the systematics and phylogenetic grouping of certain lineages are discussed in light of the present cytogenetic results. In some cases, variation of chromosome markers was observed to correspond with variation in other evolutionary traits, which is related to the processes of ongoing speciation and hybridization in zones of secondary contact. It was concluded that the physical mapping of rDNA sequences and heterochromatin may be used as an additional marker for understanding interspecific relationships in these groups and their routes of speciation.
\end{abstract}

Keywords: FISH, rDNA, Heterochromatin, Evolution, Orthoptera, Poecilimon, Isophya

\footnotetext{
* Correspondence: grzywacz@isez.pan.krakow.pl

${ }^{1}$ Institute of Systematics and Evolution of Animals Polish Academy of

Sciences, Sławkowska 17, Krakow 31-016, Poland

Full list of author information is available at the end of the article
} 


\section{Background}

Isophya and Poecilimon represent the most evolutionarily successful genera of the tribe Barbitistini (sometimes regarded as a subfamily), accounting for about $82 \%$ species of this taxon. Both genera represent herbivorous short-winged bushcrickets with complex acoustic behavior [1]. Their center of diversification and, possibly, origin, is the Pontic region, and especially Anatolia, which is home to a vast number of taxa (a total of 136 Poecilimon species and 86 Isophya species; [2,3]) with restricted ranges [4,5]. A great number of taxa are local endemics; nevertheless, they often occur in huge numbers and thus may damage crops $[6,7]$.

Several attempts to classify these two groups have been made, mainly on a smaller scale (within genera) and using various approaches, such as morphology $[6,8,9]$, bioacoustic and morphological traits [5,10-17], cytogenetic data [18-20], and molecular phylogenies [21,22]. Yet, many questions and doubts remain unanswered due to the large number of taxa, the vast recent radiation in some lineages and, possibly, the considerable contribution of present and past hybridization events $[5,20]$.

Ribosomal DNA genes (rDNA) and active nucleolus organizer regions (NORs) are very useful chromosome markers for interspecific comparisons. Over the last few years, fluorescence in situ hybridization (FISH) techniques have been extensively used for understanding the karyotype structure and evolution of various insects, especially coleopterans (e.g. Scarabaeinae [23]), lepidopterans [24], and orthopterans (e.g. Acrididae grasshoppers) [25-30]. In other Orthoptera, e.g. tettigoniids, repeated DNA has been analyzed by silver impregnation (Ag-NORs) and chromosomal mapping with a view to location of the major ribosomal DNA cluster (18S rDNA probe) and telomere repeats $\left(\right.$ TTAGG) ${ }_{n}$ in the subfamilies Saginae [31,32], Bradyporinae [33], and Phaneropterinae [20,34-36].

To date, the chromosomal organization (i.e. the distribution of heterochromatin and the location of $18 \mathrm{~S}$ loci and active NORs) of Barbitistini was analyzed in species belonging to eight genera of this tribe. In these lineages the latter markers proved to be good for understanding genomic differentiation and distinguishing between species and evolutionary lines [37]. In this work, we present a detailed cytogenetic analysis of 79 taxa belonging to the genera Poecilimon and Isophya. We examined their chromosomal characteristics, the number and distribution of major rDNA clusters using FISH with an 18S rDNA probe, and active NOR locations by silver staining. In FISH experiments, we also used the telomeric (TTAGG) probe for better identification of chromosome ends. In addition, some Isophya species/subspecies/populations for which rDNA cluster data were previously available [20] were included in our analysis. Furthermore, conventional methods, such as C-banding and fluorochrome $\mathrm{CMA}_{3}$ and DAPI staining, were used to analyze heterochromatin composition in representatives of both genera. The main objectives of the present work were to test (1) how the structure and distribution of rDNA clusters and heterochromatin affect the genomic organization of Poecilimon and Isophya, (2) whether the general tendencies in chromosomal organization correspond to morphoacoustic specializations, and (3) whether these tendencies reflect recent concepts concerning the systematics and phylogeny of both genera.

\section{Results}

All analyzed Poecilimon and Isophya species showed a $2 \mathrm{n}=31$ karyotype in the males and a $2 \mathrm{n}=32$ karyotype in the females with an X0/XX sex determination system. Acrocentric autosomes were divided into two groups: four long (1-4) and eleven medium or short ones (5$15)$, both of which gradually decreased in size and sometimes minor length differences in chromosome pairs might cause problems with their precise identification. Combining the results of all cytogenetic markers allowed for the identification of homologous chromosome targets, yet sometimes the ordering of particular pairs could be imprecise. In most Poecilimon species, the $\mathrm{X}$ chromosome was acrocentric, except for subacrocentric chromosomes in P. jonicus tessellatus, P. martinae, and P. macedonicus (Table 1). Similarly to the results published previously [19], most Isophya species analyzed in this study exhibited a subacrocentric X (Table 2).

\section{Cytogenetic mapping of ribosomal and telomeric DNA and NORs}

Cytogenetic maps of 18S rDNA were obtained for 39 Poecilimon taxa (Table 1) and 40 Isophya taxa (taken together with those previously published [20]) (Table 2). Representative hybridized metaphasic chromosomes or bivalents are shown in Figures $1 \mathrm{a}-\mathrm{h}, 1 \mathrm{a}^{\prime}-\mathrm{h}$ ' and $2 \mathrm{a}-\mathrm{i}$, and $2 a^{\prime}-i^{\prime}$. In both genera, the number of rDNA sites per haploid genome ranged from one to five; they were located on the autosomes, and rarely on the sex chromosome - in P. macedonicus (Figure 1e), P. marmaraensis (not shown), P. ukrainicus/fussii (Figure 1f), and also $I$. pavelii ([20] - see Figure 2a), I. major (not shown), and one population of $I$. rectipennis (Figure 2e).

Most Poecilimon taxa carried one (50\%) or two (45\%) rDNA loci, and only two species exhibited four loci (5\%). When a single rDNA cluster was detected, it was always located on a small pair near the paracentromeric region (one of the pairs 9-12; Figure 1a,b); only in P. jonicus tessellatus it appeared in the interstitial region (not shown). Two rDNA clusters were evident on long/medium and short chromosome pairs near the paracentromeric region (Figure 1c,d), except for P. macedonicus (distal location on the $\mathrm{X}$ chromosome; Figure 1e) and $P$. aff. glandifer 
Table 1 Poecilimon species: collection localities, sex chromosome types (X), and chromosomal location of rDNA clusters

\begin{tabular}{|c|c|c|c|c|c|}
\hline & \multirow[t]{2}{*}{ Species } & \multirow[t]{2}{*}{ Collection sites } & \multirow[t]{2}{*}{$\mathrm{X}$} & \multicolumn{2}{|c|}{ rDNA-FISH signal } \\
\hline & & & & Localization & $\overline{\text { Total }}$ \\
\hline \multirow[t]{10}{*}{1} & P. ledereri Ramme, 1933 & TR, Izmir prov., Izmir & $\mathrm{a}$ & $11 / 13 p$ & 1 \\
\hline & P. aff. ledereri Ramme, 1933 & TR, Karabük prov., Agaçkesen Köyü & a & $11 / 12 p$ & 1 \\
\hline & P. orbelicus Pancic, 1883 & BG, Blagoevgrad distr., Rila Mts, Eleshnitsa & a & $11 / 12 p$ & 1 \\
\hline & P. armeniacus (Uvarov, 1921) & TR, (1) Tokat/Sivas prov. border, Çamlibel pass; & a & (1) $9 / 10 p$; & 1 \\
\hline & & (2) Agri prov., Balik Gölü & & (2) $11 / 13 p$ & 1 \\
\hline & $\begin{array}{l}\text { P. ampliatus Brunner von } \\
\text { Wattenwyl, } 1878\end{array}$ & SL, Slavnik Mt. & a & $2 / 3,9 / 10 p$ & 2 \\
\hline & P. pechevi Andreeva, 1978 & BG, Blagoevgrad distr., Vlahina Mt., Kadiytsa Peak & a & $3 / 4 p, 12 / 13 p$ & 2 \\
\hline & P. ebneri Ramme, 1933 & MK, Mariovo Region, W of Skochivir vill. & a & $3 / 4^{*} p, 12 / 13 p$ & 2 \\
\hline & P. klisuriensis Willemse, 1982 & MK, Baba (Pelister) Mt., Gjavato pass & a & $5 p, 11 p$ & 2 \\
\hline & P. marmaraensis Naskrecki, 1991 & BG, Sliven distr., E Stara Planina Mt. & a & $4 / 5 p, X p$ & 2 \\
\hline \multirow[t]{4}{*}{2} & P. cf. karakushi Ünal, 2003 & TR, Isparta prov., S Taurus Mts, Davras Resort & a & $11 / 13 p$ & 1 \\
\hline & P. ersisi Salman, 1978 & TR, Tokat/Sivas prov. border, Çamlibel pass & a & $11 / 13 p$ & 1 \\
\hline & P. serratus Karabag, 1962 & TR, Bursa prov., Keles & a & $11 / 12 p$ & 1 \\
\hline & P. toros Ünal, 2003 & TR, Antalya & $\mathrm{a}$ & $12 / 13 p$ & 1 \\
\hline \multirow[t]{11}{*}{3} & P. cervus Karabag, 1950 & TR, Düzce prov., above Yıgılca & $\mathrm{a}$ & $9 p$ & 1 \\
\hline & P. pliginskii Miram, 1929 & UA, S Crimea, Chetyr Dag Mt. & a & $10 / 11 p$ & 1 \\
\hline & P. aff. bischoffi Ramme, 1933 & UA, S Crimea, Angarskiy Pereval Pass & $\mathrm{a}$ & $10 / 11 p$ & 1 \\
\hline & P. bischoffi Ramme, 1933 & TR, Rize prov., Ikizdere & a & $11 / 13^{*} p$ & 1 \\
\hline & $\begin{array}{l}\text { P. bosphoricus Brunner von } \\
\text { Wattenwyl, } 1878\end{array}$ & TR, Kastamonu prov., Ilgaz Mt., Tosya pass & a & $10 p$ & 1 \\
\hline & P. miramae Ramme, 1933 & BG, Haskovo distr., E Rhodope Mts, Mandritsa vill. & a & $9 / 10 p$ & 1 \\
\hline & P. heinrichi (Ramme, 1951) & BG, Bourgas distr., Strandza Mts, near Malko Tarnovo & a & $12 / 13 p$ & 1 \\
\hline & P. roseoviridis Chobanov \& Kaya, 2012 & BG, (1) Bourgas distr., Kovach site; (2) Malko Tarnovo & a & $3 / 4 p, 9 / 11 p$ & 2 \\
\hline & P. turcicus Karabag, 1950 & TR, Kırklareli prov., Mandraköy vill. & a & $3 / 4 p, 11 / 13 p$ & 2 \\
\hline & P. anatolicus Ramme, 1933 & TR, Tekirdag prov., Elmali vill. & a & $3 / 4^{*} p, 11 / 13 p$ & 2 \\
\hline & P. similis proximus Ünal, 2010 & TR, Düzce prov., near Yigilca & a & $4 p, 12 / 13 p$ & 2 \\
\hline 4 & P. chopardi Ramme, 1933 & MK, Nidzhe Mt., above Skochivir vill. & a & $5 p, 13 p$ & 2 \\
\hline \multirow[t]{4}{*}{5} & P. brunneri (Frivaldsky, 1867) & GR, Thrakien Rodopi; BG, Bourgas, Malko Tarnovo & a & $11 / 13 p$ & 1 \\
\hline & $\begin{array}{l}\text { P. ukrainicus Bey-Bienko, 1954/fussii } \\
\text { Fieber, } 1878\end{array}$ & BG, Rousse distr., Byala \& Ivanovo vill. & $a$ & $5 p, x p$ & 2 \\
\hline & P. macedonicus Ramme, 1926 & GR, Kalambaca; MK, Nidzhe Mt., above Skochivir vill. & sa & $13 p, X d$ & 2 \\
\hline & P. zwicki Ramme, 1939 & BG, Blagoevgrad distr., Maleshevska Planina Mt. & a & $2 d^{*}, 5 d, 7 p, 9 d$ & 4 \\
\hline \multirow[t]{2}{*}{6} & P. jonicus tessellatus (Fischer, 1853) & GR, Peloponnes & sa & $12 / 13 i$ & 1 \\
\hline & P. martinae Heller, 2004 & TR, Antalya & sa & $11 / 12 p$ & 1 \\
\hline \multirow[t]{2}{*}{7} & P. schmidtii (Fieber, 1853) & $\begin{array}{l}\text { BG, (1) Varna distr., St.St. Konstantin and Elena Resort - Botanical Garden; } \\
\text { (2) Vidin distr., Belogradchik }\end{array}$ & a & $3 / 4 p, 6 / 7 p$ & 2 \\
\hline & P. zonatus Bolívar,1899/varicornis (Haan,1842) & TR, Van prov., Kuskunkıran pass & a & $4 / 5 p, 10 / 13 p$ & 2 \\
\hline \multirow[t]{3}{*}{3} & $\begin{array}{l}\text { P. jablanicensis Chobanov \& } \\
\text { Heller, } 2010\end{array}$ & MK, Jablanica Mt., above Gorna Belica vill. & a & $3 / 4^{*} p, 7 p$ & 2 \\
\hline & P. ornatus (Schmidt, 1850) & SL, Slavnik/Garbice & a & $3 / 4 p, 12 / 13 p$ & 2 \\
\hline & P. affinis (Frivaldsky, 1867) & $\begin{array}{l}\text { BG, (1) Kyustendil distr., Rilski Manastir; (2) Vratsa distr., } \\
\text { Vrachanska Planina Mt. }\end{array}$ & $a$ & $2 p, 5 p, 7 p, 13 p$ & 4 \\
\hline
\end{tabular}


Table 1 Poecilimon species: collection localities, sex chromosome types (X), and chromosomal location of rDNA clusters (Continued)

\begin{tabular}{|c|c|c|c|}
\hline ? P. ataturki Ünal, 1999 & TR, Kastamonu prov., Devrekani towards Yaraligöz Pass & $\bar{a}$ & $12 / 13 p$ \\
\hline ? P. celebi Karabag, 1953 & TR, Kastamonu prov., Devrekani towards Yaraligöz Pass & a & $2 / 3 p, 11 / 13 p$ \\
\hline ? P. aff glandifer Karabag, 1950 & TR, lzmir prov., 18 km N of Ödemiş & a & $3 / 4 i-d^{*}, 10 / 12 p$ \\
\hline
\end{tabular}

BG = Bulgaria, MK = Macedonia, SL = Slovenia, GR = Greece, TR= Turkey, UA = Ukraine; X-type: $a=$ acrocentric, sa = subacrocentric; total = number of clusters in haploid genome; a slash between two numbers indicates imprecise identification of the chromosome pair (bivalent); $p=$ paracentromeric; $d=$ distal; $i=i n t e r s t i t i a l ; i-d=i n t e r s t i t i a l$ near the distal end; $X$ = sex chromosome; *high or low activity between homologous chromosomes. The first column shows groups of species/phylogenetic lineages as suggested in published sources and/or inferred from unpublished own data: 1 - node $C$ according to Ullrich et al. [22] or $P$. ampliatus group s.l. see [10]; 2 - $P$. syriacus group [14]; 3 - P. bosphoricus group [17]; 4 - P. propinquus group [10]; 5 - node A according to Ullrich et al. [22] or $P$. brunneri group [10] s.l.; 6 - possibly belonging to a monophyletic lineage [22]; 7 - possibly belonging to a monophyletic lineage [22]; 8 - $P$. ornatus group [16]; ? - taxa with a doubtful phylogenetic position.

(interstitially near its distal region, probably on the 3rd or 4th pair; not shown). FISH revealed rDNA on four bivalents only in $P$. affinis (in the paracentromeric region; Figure $1 \mathrm{~g}$ ) and $P$. zwicki (paracentromeric or distally located; Figure 1h). While the number of $18 \mathrm{~S}$ rDNA loci varied from one to five in Isophya, most species showed two locations (62.7\%); rarely one (11.8\%), three $(11.8 \%)$, four $(7.8 \%)$, or five $(5.9 \%)$ clusters (including polymorphism between populations in some species) (Figure $2 \mathrm{a}-\mathrm{i}$ ). Most $18 \mathrm{~S}$ rDNA loci were situated in different-sized autosomes in the paracentromeric region, however distally to the centromere on a long pair (3) in I. straubei ssp. (not shown), as well as on the subacrocentric $\mathrm{X}$ chromosome and a medium-sized bivalent (pair 5) in I. rectipennis from both Bulgarian populations (Figure 2e and see Figure 2c,d in [20]).

Individuals from different populations demonstrated the same rDNA-FISH signal location in Poecilimon brunneri, $P$. roseoviridis, $P$. macedonicus, $P$. schmidtii, Isophya miksici, I. longicaudata longicaudata, I. modestior (from Bulgarian populations), I. rhodopensis petkovi, and I. tosevski. On the other hand, interpopulation variation in the rDNA signal pattern observed in $P$. armeniacus and I. rectipennis (Figure 2e,f), was also previously reported in I. bureschi, I. rhodopensis rhodopensis, and I. rh. rhodopensis/I. rh. leonorae intermediate forms [20] (Table 1 and 2). Sometimes the rDNA cluster varied in size between homologous chromosomes (Table 1 and 2, see the chromosome number marked with an asterisk; Figures 1' and 2a',c',e', ','i').

FISH with the (TTAGG) ${ }_{n}$ probe (tDNA-FISH) was used for spermatogonial or oogonial mitosis and spermatocyte nuclei at different stages of meiosis. In all species of both genera, tDNA-FISH signals were detected at the distal ends of most chromosomes, but showed variation in size and intensity on the autosomes and $\mathrm{X}$ chromosomes in some species (Figure 1a-h; 2a-i).

In all the species examined in the present study, rDNAFISH signals were co-localized with the active NORs visualized by $\mathrm{AgNO}_{3}$ staining (Figures $1 \mathrm{i}-\mathrm{l}, 2 \mathrm{j}-\mathrm{m}$ ). A lack of a full congruency between rDNA location and NOR activity has been previously reported for some autosomes and the $\mathrm{X}$ chromosome only in four Isophya species [20].

\section{Heterochromatin patterns revealed by banding techniques}

Table 3 shows variation among the analyzed species and genera using $\mathrm{C}$-banding (only double/thick C-bands) and DAPI/CMA 3 patterns. Heterochromatin blocks can be characterized as DAPI-/CMA ${ }_{3}+$ (GC-rich), DAPI+/ $\mathrm{CMA}_{3}$ - (AT-rich) or DAPI+/CMA + (containing both AT- and GC-rich regions). Generally, thick C-bands on most chromosomes showed bright DAPI+ and $\mathrm{CMA}_{3}+$ signals in pericentromeric or, rarely, interstitial or distal regions. In such cases, DAPI and $\mathrm{CMA}_{3}$ blocks were located very close to each other, but only bright $\mathrm{CMA}_{3}$ signals coincided with $18 \mathrm{~S}$ rDNA and active NORs (Figure 3a,b). In some species AT-bands were not detected (designated as DAPI- and marked as " 0 " in Table 2), while bright $\mathrm{CMA}_{3}+$ bands were co-localized with rDNAFISH/NOR signals (Tables 1, 2, 3; Figure 3c-d). Unfortunately, it was not possible to separate DAPI/CMA 3 regions to compare them with rDNA locations in Poecilimon bischoffi, P. orbelicus, $P$. aff. ledereri, and P. marmaraensis.

Some species in both studied genera exhibited heteromorphism in terms of rDNA-FISH signal size/strength and $\mathrm{C} / \mathrm{DAPI} / \mathrm{CMA}_{3}$ bands between homologue chromosomes or different-sized autosomes (as indicated with an asterisk in Tables 1, 2, 3); for example, in P. zwicki (Figure 1h'), I. thracica (Figure 2a'), I. cf. armena (Figure 2c'), I. rectipennis (Turkish and Bulgarian populations; Figure 2e',f'), I. yaraligozi (Figure 2i'), and Isophya sp. (Figure 3d).

\section{Discussion}

By mapping rDNA (and also potential NORs) and two heterochromatin classes we set out to determine whether these methods may be used to identify chromosome markers useful for studying the genomic organization and diversity of Poecilimon and Isophya and for distinguishing evolutionary lineages. The differences and similarities revealed between the two genera are listed below.

\section{Differences in genome organization revealed by cytogenetic markers}

Given the stable karyotype in both genera $(2 n=31)$, variation in the number of acrocentric chromosomes involved 
Table 2 Isophya species: collection localities, sex chromosome types (X), and chromosomal location of rDNA clusters

\begin{tabular}{|c|c|c|c|c|c|}
\hline \multirow{2}{*}{\multicolumn{2}{|c|}{ Species }} & \multirow[t]{2}{*}{ Collection sites } & \multirow[t]{2}{*}{$\mathrm{X}$} & \multicolumn{2}{|l|}{ rDNA-FISH signal } \\
\hline & & & & Localization & Total \\
\hline \multirow[t]{2}{*}{1} & I. hospodar (Saussure, 1898) & BG, Sofia distr., Beledie Han & sa & $3 p, 10 / 12 p$ & 2 \\
\hline & 1. straubei ssp. & TR, Isparta prov., S Taurus Mts, Davraz Resort & sa & $3 d^{*}, 6 p$ & 2 \\
\hline \multirow[t]{8}{*}{2} & I. nervosa Ramme, 1931 & TR, Kütahya prov., E of Tavşanlı & a & $3 p$ & 1 \\
\hline & 1. thracica Karabag, 1962 & TR, Tekirdag prov., Elmalı vill. & sa & $13^{*} p$ & 1 \\
\hline & I. stenocauda stenocauda Ramme, 1951 & TR, Karabük prov.,Agaçkesen Köyü & sa & $10 / 12 p$ & 1 \\
\hline & I. stenocauda obenbergeri Mařan, 1958 & TR, Kastamonu prov., Tosya pass & sa & $3 p, 11 / 12^{*} p$ & 2 \\
\hline & \multirow{3}{*}{$\begin{array}{l}\text { I. rectipennis Brunner von } \\
\text { Wattenwyl, } 1882\end{array}$} & BG, Rousse distr., Byala; & sa & $7^{*} p, x d$ & 2 \\
\hline & & TR, Düzce prov., above Yıgılca; & a & $3 p, 12 / 13^{*} p$ & 2 \\
\hline & & -BG, Sliven distr., E Stara Planina Mts, Karandila & a & $3 / 4 p, 5 d$ & 2 \\
\hline & I. pavelii Brunner von Wattenwyl, 1882 & BG, Strandzha Mts & a & $2 p, 3 / 4^{*} p, X p$ & 3 \\
\hline \multirow[t]{18}{*}{3} & \multirow[t]{4}{*}{ 1. bureschi Peshev, 1981 - } & BG, (1) Blagoevgrad distr., Rila Mts, Jundola vill; & \multirow[t]{4}{*}{ sa } & (1) $3 / 4 p, 11 / 12 p$ & (1) 2 \\
\hline & & (2) Pazardzhik distr., Sredna Gora Mts, Oborishte hut; & & (2) $11 / 12 p ;$ & (2) 1 \\
\hline & & (3) Blagoevgrad distr., Pirin Mts, Gotse Delchev lodge; & & (3) $3 / 4^{*} p, 11 / 12 p$; & (3) 2 \\
\hline & & (4) Sofia distr., near Plana vill. & & (4) $11 / 12 p$ or $4 p, 11 / 12 p$ & (4) $1 / 2$ \\
\hline & I. andreevae Peshev, 1981 & BG, Blagoevgrad distr., Kresna Gorge & sa & $3 / 4 p, 10 / 11 p$ & 2 \\
\hline & I. miksici Peshev, 1985 & $\begin{array}{l}\text { BG, (1) Vratsa distr., Vrachanska Planina Mt., Gorski Dom hotel; } \\
\text { (2) Danubian Plane }\end{array}$ & sa & $2 / 3 p, 12 / 13 p$ & 2 \\
\hline & I. plevnensis Peshev, 1985 & BG, Lovech distr., Apriltsi & sa & $2 / 3 p 12 / 13 p$ & 2 \\
\hline & $\begin{array}{l}\text { I. longicaudata adamovici } \\
\text { Peshev, } 1985\end{array}$ & BG, Sliven distr., E Stara Planina Mts, Karandila & sa & $3 / 4 p, 12 / 13^{*} p$ & 2 \\
\hline & $\begin{array}{l}\text { I. longicaudata longicaudata Ramme } \\
\text { 1951. }\end{array}$ & $\begin{array}{l}\text { BG, (1) Varna distr., St.St. Konstantin and Elena resort; } \\
\text { (2) Silistra distr., Balik and Pchelnik vills }\end{array}$ & sa & $3 / 4 p, 12 / 13 p$ & 2 \\
\hline & $\begin{array}{l}\text { 1. rhodopensis leonorae } \\
\text { Kaltenbach, } 1965\end{array}$ & BG, Blagoevgrad distr., Alibotush Mt, Livade site & sa & $\begin{array}{l}2 / 3 p, 3 / 4 p, 6 / 7 p, 8 p \\
12 / 13 p\end{array}$ & 5 \\
\hline & I. rh. petkovi Peshev, 1959 & $\begin{array}{l}\text { BG, (1) East Rhodope Mts, Perperikon site near Murgovo vill.; } \\
\text { (2) E Rhodope Mts, Gluhite Kamani site }\end{array}$ & sa & $3 / 4 p, 5 / 6 p, 7 / 8 p, 12 / 13 p$ & 4 \\
\hline & \multirow[t]{2}{*}{ 1. rh.. rhodopensis Ramme 1951 } & \multirow[t]{2}{*}{ BG, Smolyan distr., Rodope Mts, above Smolyan } & \multirow[t]{2}{*}{ sa } & $\begin{array}{l}3 / 4 p, 5 p, 6^{*} p, 8 / 9 p \\
12 / 13 p\end{array}$ & 5 \\
\hline & & & & $3 / 4 p, 5 p, 8 / 9 p, 12 / 13$ & 4 \\
\hline & \multirow{3}{*}{$\begin{array}{l}\text { I. rh. rhodopensis / I. rh. leonorae } \\
\text { Kaltenbach, } 1965 \text { - intermediate/hybrid } \\
\text { populations }\end{array}$} & \multirow{3}{*}{$\begin{array}{l}\text { BG, (1), Smolyan distr., W Rhodope Mts, Trigrad vill.; (2) Smolyan, } \\
\text { W Rodope Mts, near Shiroka Polana Lake; (3) Smolyan distr., } \\
\text { W Rhodope Mts, Trigrad-Zhrebevo vills }\end{array}$} & \multirow[t]{3}{*}{ sa } & (1) $3 / 4 p, 5 / 6 p, 12 / 13^{*} p$; & (1) 3 \\
\hline & & & & (2) $3 / 4 p, 12 / 13 p ;(2) \&(3)$ & (2) 2 \\
\hline & & & & $\begin{array}{l}3 / 4^{*} p, 5^{*} p, 6 / 7^{*} p, 12 / 13^{*} p \\
\text { or } 3 / 4 p, 5 / 6 p, 12 / 13^{*} p\end{array}$ & (3) $4 / 3$ \\
\hline & I. yaraligozi Ünal, 2003 & TR, Kastamonu prov., Yaraligoz Pass & sa & $1^{*} p, 3^{*} p, 7^{*} p, 11 p$ & 4 \\
\hline & I. tosevski Pavicevic, 1983 & $\begin{array}{l}\text {-MK, (1) Doiran lake near Nikolich vill.; (2) Mariovo range, } \\
\text { Moklishte vill. }\end{array}$ & sa & $\begin{array}{l}3 / 4 p, 5 p, 6 p, 7 / 8 p \\
12 / 13 p\end{array}$ & 5 \\
\hline \multirow[t]{6}{*}{4} & I. taurica Brunner von Wattenwyl, 1878 & UA, S Crimea, Babugan Yayla plateau & sa & $12 / 13 p$ & 1 \\
\hline & I. gulae Peshev, 1981 & BG, Yambol distr., Elhovo, $100 \mathrm{~m}$ & sm & $2 / 3 p, 12 / 13 p$ & 2 \\
\hline & I. obtusa Brunner von Wattenwyl, 1882 & BG, Lovech distr., C Stara Planina Mts, Pleven lodge & sa & $2 / 3 p, 12 / 13$ & 2 \\
\hline & $\begin{array}{l}\text { I. camptoxypha (Fieber, 1854) or I. } \\
\text { posthumoidalis Bazyluk, 1971 }\end{array}$ & PL, Tatra Mts & sa & $3 / 4 p, 11 / 12 p$ & 2 \\
\hline & I. altaica Bey-Bienko, 1926 & RU, Altai Mts & sm & $3 p, 12 / 13$ & 2 \\
\hline & I. brunneri (Fraivaldsky, 1867) & UA, Crimea, Chatyr Dag, 1250 m \& Babugan Yayla & sm & $7 p, 9 p$ & 2 \\
\hline \multirow[t]{2}{*}{5} & \multirow{2}{*}{$\begin{array}{l}\text { I. modestior Brunner von } \\
\text { Wattenwyl, } 1882\end{array}$} & BG, (1) Vidin distr., Belogradchik; (2) Sofia distr., Vitosha Mt; & \multirow[t]{2}{*}{ sa } & $3 / 4^{*} p, 5 / 6 p$ & 2 \\
\hline & & -SR, Novi Sad distr., near Kamenitsa vill & & $1 / 2 p, 3 / 4^{*} p$ & 2 \\
\hline
\end{tabular}


Table 2 Isophya species: collection localities, sex chromosome types (X), and chromosomal location of rDNA clusters (Continued)

\begin{tabular}{|c|c|c|c|c|c|}
\hline \multirow[t]{2}{*}{6} & $\begin{array}{l}\text { 1. kraussii Brunner von } \\
\text { Wattenwyl, 1878 }\end{array}$ & GR, Bavaria & $\mathrm{sm}$ & $2 p, 3 / 4 p$ & 2 \\
\hline & I. pienensis Maran, 1954 & PL, Bieszczady Mts & $\mathrm{sm}$ & $1 / 2^{*} p, 3 / 4 p$ & 2 \\
\hline \multirow[t]{3}{*}{7} & Isophya sp. & TR, Erzurum prov., Ovit pass & sa & $1 / 2^{*} p, 10 / 12 p$ & 2 \\
\hline & I. zernovi Miram, 1938 & TR, Artvin prov., near Kafkasor & sa & $3^{*} p, 11 / 12^{*} p$ & 2 \\
\hline & I. autumnalis Karabag, 1962 & TR, Gümüşhane prov., Zigana pass & sa & $2 / 4 p, 10 / 12 p$ & 2 \\
\hline \multirow[t]{2}{*}{8} & I. cf. armena Miram, 1938 & TR, Sivas prov., Zara-Suşehri road & sa & $3^{*} p, 6 p$ & 2 \\
\hline & $\begin{array}{l}\text { I. schneideri Brunner von } \\
\text { Wattenwyl, } 1878\end{array}$ & TR, Ardahan prov., Ardahan-Çıldır & a & $3 p, 6 p, 7 p$ & 3 \\
\hline \multirow[t]{5}{*}{9} & I. sureyai Ramme, 1951 & TR, Sivas prov., Zara-Suşehri road & sa & $3 p, 11 / 12 p$ & 2 \\
\hline & I. aff. sureyai Ramme, 1951 & TR, Giresun prov., Tamdere & a & $5 / 6 p, 12 / 13 p$ & 2 \\
\hline & I. speciosa (Frivaldsky, 1867) & BG, (1) Rodope Mts \& Stara Planina; (2) Byala & sa & $1 / 2 p, 3 / 4 p$ & 2 \\
\hline & $\begin{array}{l}\text { I. amplipennis Brunner von } \\
\text { Wattenwyl, } 1878\end{array}$ & TR, Bilecik prov., near Sögüt & sa & $5 / 6 p, 10 p$ & 2 \\
\hline & I. rizeensis Sevgili, 2003 & TR, Rize prov., Ikizdere & a & $3 p, 5 p, 11 p$ & 3 \\
\hline 10 & I. major Brunner von Wattenwyl, 1878 & TR, Antalya prov., Kuruçay & sa & $1 / 2 p, 10 / 12 p, x p$ & 3 \\
\hline
\end{tabular}

BG = Bulgaria, GR = Germany, MK = Macedonia, PL = Poland, RU = Russia, SR = Serbia, TR = Turkey, UA = Ukraine; •published by Grzywacz et al. 2011; X-type: $\mathrm{a}=$ acrocentric, $\mathrm{sa}=$ subacrocentric, $\mathrm{sm}=$ submetacentric; total = number of clusters in haploid genome; a slash between two numbers indicates imprecise identification of the chromosome pair (bivalent); $\mathrm{p}=$ paracentromeric; $\mathrm{d}=$ distal; * high or low activity between homologous chromosomes. The first column shows groups of species/ phylogenetic lineages as suggested in published sources and/or inferred from unpublished own data: $1-I$. straubei group [5]; $2-I$. rectipennis group [5]; $3-I$. modesta group [5]; 4 - I. pyrenaea group [5]; 5 - I. costata group [5]; 6 - I. kraussii group [5]; 7 - I. zernovi group [46]; 8 - I. schneideri group [5,46]; 9 - I. speciosa group [5]; 10- I. major group [12].

only the sex chromosomes. This could be due to the occurrence of a pericentric inversion that converted the original/ancestral acrocentric X chromosome to a subacro-/ submetacentric one. These karyotype characteristics were found in 35 out of 42 Isophya taxa (present study; [19]), but in only three out of 39 Poecilimon species/subspecies (present study; [38]). Thus, changes in the morphology of the $\mathrm{X}$ chromosomes are common in Isophya, in contrast to Poecilimon and other Barbitistini [39].

Based on the number of rDNA clusters, the genus Poecilimon was divided into two main, almost equal, groups carrying the FISH signal on one or two chromosomes. In turn, the prevalent number of rDNA locations in Isophya was two, while either one or 3-5 locations occurred in some cases. Three rDNA clusters were usually connected with a large amount of heterochromatin in the chromosome set (also [19] for Isophya). A high number of NORs/rDNA loci with variable positions is characteristic of some other Barbitistini (Barbitistes, Polysarcus, Phonochorion; [37]), involving groups of species of recent origin. In both analyzed genera, most species had rDNA on one or two chromosomes, which makes it difficult, especially in Poecilimon, to assess their ancestral status. The presence of paracentromeric rDNA loci only on a single bivalent was previously observed in other Phaneropterinae species: the European Odontura [36] and Phaneroptera falcata [40], as well as in the African Lunidia viridis [34] and four species of the genus Eurycorypha [35]. In other Tettigoniidae, single rDNA-positive FISH signals have been observed in European representatives of Saginae and Bradyporinae $[32,35]$. In addition, one active NOR seems to be a typical feature of karyotypes with the ancestral chromosome number in Tettigoniinae [41].

Thick $\mathrm{C} / \mathrm{DAPI} / \mathrm{CMA}_{3}$ bands were observed on most chromosomes in Poecilimon suggesting the presence of more families of repetitive DNA sequences in this genus as compared to the heterochromatin patterns in Isophya. Thus, these bands appear to be a feature differentiating the karyotypes of the two genera (Table 3). A high amount of heterochromatin was earlier reported for some other genera of Barbitistini [37].

\section{Similarities in genome organization revealed by cytogenetic markers}

All the studied species had an ancestral (for Tettigoniidae) diploid chromosome number, and thus the variability in the number and location of rDNA loci probably resulted from transposition involving mobile elements or ectopic recombination. Similar mechanisms have been suggested for Acrididae [25], Lepidoptera [24], and Scarabaeinae [23]. Generally, rDNA loci are coincident with active NORs and GC-rich heterochromatin, which indicates the presence of multiple repetitive DNA sequences. Some species in both genera showed different intensities of rDNA hybridization signals on homologous pairs of autosomes, and also heteromorphism in the pattern of heterochromatin distribution (indicated by an asterisk in 


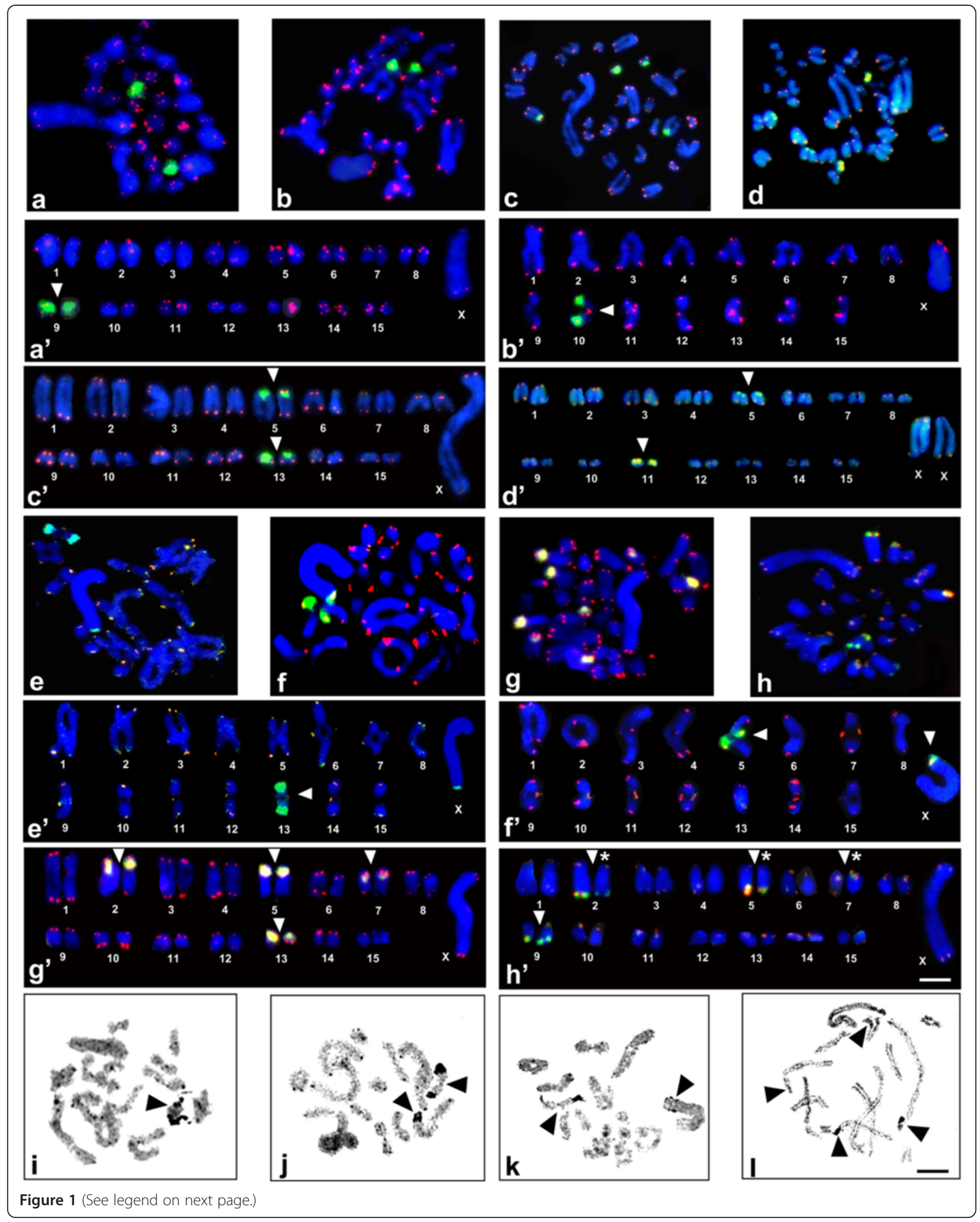


(See figure on previous page.)

Figure 1 Examples of FISH with both $18 \mathrm{~S}$ rDNA (green) and telomeric DNA (red) probes in spermatogonial metaphase (a, c, d, g, h) or diakinesis $(b, e, f)$, as well as karyotypes arranged from these divisions $\left(a^{\prime}-h^{\prime}\right)$ and silver staining in diakinesis (i-k) and diplotene $(I)$ of chromosomes for the following Poecilimon species: P. cervus $\left(a, a^{\prime}\right), P$. bosphoricus $\left(b, b^{\prime}, i\right), P$. chopardi $\left(c, c^{\prime}, j\right), P$. klisuriensis $\left(d, d^{\prime}\right)$, P. macedonicus $\left(\mathrm{e}, \mathrm{e}^{\prime}, \mathbf{k}\right), \boldsymbol{P}$. ukrainicus/fussii $\left(\mathbf{f}, \mathbf{f}^{\prime}\right), \boldsymbol{P}$. affinis $\left(\mathbf{g}, \mathbf{g}^{\prime}\right)$, and $\boldsymbol{P}$. zwicki $\left(\mathbf{h}, \mathbf{h}^{\prime}, \mathrm{l}\right)$. White arrowheads point to rDNA clusters near the centromeric or distal regions of the chromosomes. Hybridization areas vary in size between some homologous chromosomes, which are marked with an asterisk $(*)$. Black arrowheads indicate the presence of one (i), two (j, $\mathbf{k})$, or four $(\mathbf{I})$ active NORs. 185 rDNA signals in mitotic metaphase/ diakinesis coincide with NORs. Bar $=10 \mu \mathrm{m}$.

Tables 1, 2, 3). These differences were detected consistently by all the banding techniques used and observed in those chromosomes in which heterochromatin occurred in large quantities (i.e. in the form of large paracentromeric heterochromatic blocks). Such intraspecific polymorphism may be the result of different mechanisms, i.e. tandem duplication of ribosomal genes, unequal meiotic crossing-over, translocation rearrangements, or homologous recombination $[23,42,43]$.

Our results point to some general patterns in the structure of heterochromatin and NOR/18S rDNA locations: (1) DAPI and $\mathrm{CMA}_{3}$ staining cause bright fluorescence co-occurring with thick paracentromeric C-blocks, suggesting the presence of a high number of AT- and CGbase pairs; (2) sometimes $\mathrm{CMA}_{3}$ does not detect active NORs but a special type of GC-rich heterochromatin associated with this region [44]; (3) NOR/rDNA-FISH regions show a bright $\mathrm{CMA}_{3}$ signal; (4) the pattern of distribution of GC-rich blocks indicates some level of dynamism in the genome content of heterochromatin areas and may be related to specific changes characterizing groups of taxa. Thus, different heterochromatin types suggest the occurrence of specific rearrangements of repetitive DNA families that have evolved during the diversification of Isophya and Poecilimon and are characteristic of certain phylogroups.

\section{A comparison of cytogenetic and taxonomic traits}

The evolution of repeated DNA families is dominated by genomic events such as duplication and spreading which may impede tracking the evolutionary history of the sequence, and thus prevent using these as genetic markers. However, in some cases we find concordance of cytogenetic data with phylogenetic traits such as morphology, bioacoustics, and molecular data. Previously published phylogenies [22] and speculations on species groupings using morphology and behavior are discussed below and summarized in Tables 1, 2, 3 (the first column). The European representatives of the Poecilimon ampliatus group (Table 1, group 1) sensu stricto [45] with monophyletic origin [22] show a more or less uniform location of two paracentromeric rDNA clusters on long and short autosome pairs, while the Anatolian species along with $P$. orbelicus (regarded as a monophyletic lineage except $P$. armeniacus [3]) exhibit only one FISH signal. This may provide additional data for refining species relationships by exploring correlations with morphological and behavioral traits $[10,45]$. Interesting examples deserving particular attention include the little known $P$. glandifer and $P$. ataturki, which were placed within the $P$. ampliatus group [46], possibly on account of having an abdominal tergal gland (a structure that is occasionally found within several groups of Barbitistini). And though their affinities have not been phylogenetically studied yet, there is some evidence (Chobanov et al., unpublished data) supporting their cytogenetic distinctness from group 1. An example of concordance of the present data with morphological, behavioral, and molecular traits is group 2, including taxa of the P. syriacus group [14]. Two groups of sibling species are divided between one and two rDNA-FISH signal positions - the P. bosphoricus group (group 3) [17] and the P. brunneri group (group 5) [10,22]. No proposed relationships between these were reflected in the chromosome markers, except for the phylogenetic affinities of representatives of the $P$. bosphoricus group with one chromosome rDNA location (P. miramae $+P$. cervus $+P$. heinrich $i+P$. bosphoricus), which are polyphyletic with respect to those with two locations $(P$. anatolicus and $P$. turcicus), according to mtDNA data [22]. The four rDNA clusters in $P$. zwicki (the last being a basal member of the P. brunneri group according to molecular data [22]) and $P$. affinis probably represent autapomorphies.

The genus Isophya shows a more complicated pattern of rDNA/heterochromatin organization than Poecilimon. In most taxa, two 18S rDNA sequences were located on two chromosome pairs. This seems to be a plesiomorphic state for the group, characteristic of the most primitive lineages [5], for example, I. hospodar, I. straubei (Table 2, group 1), and I. rectipennis (group 2). Yet, all of these exhibit quite a peculiar location of the studied markers. In some taxa, a significant variation of chromosome markers (Tables 2,3) corresponds to distinct intraspecific and intrapopulation genetic and/or morphoacoustic variation $[5,21,47]$. Three to five FISH signal-positive chromosomes have been found in taxa of recent origin and/or populations where hybridization by secondary contact of haplotypes is suspected. The latter case concerns the I. modesta group of species $[5,19]$, and especially the I. rhodopensis 


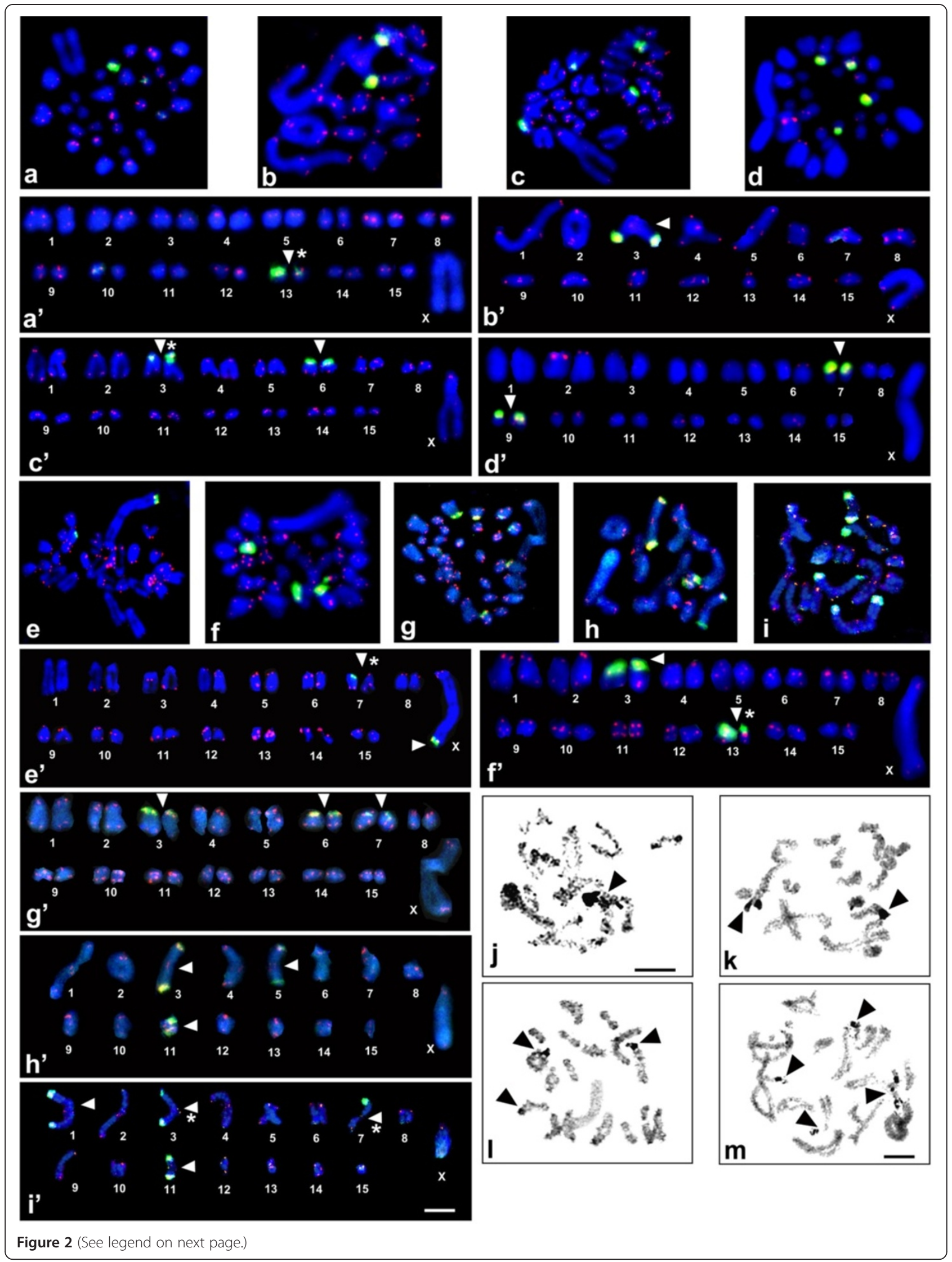


(See figure on previous page.)

Figure 2 Examples of FISH with both 18S rDNA (green) and telomeric DNA (red) probes in spermatogonial metaphases (a, c, d, e, f, g) or diakinesis $(b, h, i)$ as well as karyotypes arranged from these divisions $\left(a^{\prime}-h^{\prime}\right)$ and silver staining in diakinesis $(I)$ and diplotene $(j, k$, $\mathrm{m}$ ) of chromosomes for the following Isophya species: l. thracica $\left(a, a^{\prime}, j\right)$, l. nervosa $\left(b, b^{\prime}\right)$, l. cf. armena (c, $\left.c^{\prime}, k\right)$, l. brunneri (d, d'), I. rectipennis - Bulgarian population $\left(\mathrm{e}, \mathrm{e}^{\prime}\right)$ and Turkish population $\left(\mathrm{f}^{\prime}, \mathrm{f}^{\prime}\right), \mathrm{l}$. schneideri $\left(\mathrm{g}^{\prime}, \mathrm{g}^{\prime}, \mathrm{l}\right)$, I. rizeensis $\left(\mathrm{h}, \mathrm{h}^{\prime}\right)$, and $\mathrm{l}$. yaraligozi $\left(\mathrm{i}, \mathrm{i}^{\prime}, \mathrm{m}\right)$. In the karyotypes, white arrowheads indicate the chromosomal location of rDNA clusters and an asterisk $\left(^{*}\right)$ marks differences in size between

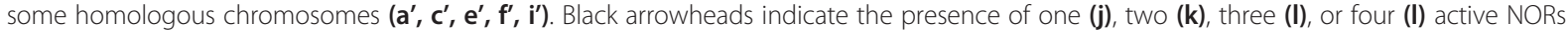
which coincide with $18 \mathrm{~S}$ rDNA signals. Bar $=10 \mu \mathrm{m}$.

Table 3 Heterochromatin patterns; localization of C-bands, DAPI and CMA 3 signals in Poecilimon and Isophya species

\begin{tabular}{|c|c|c|c|c|}
\hline & \multirow[t]{2}{*}{ Species } & \multirow[t]{2}{*}{ Thick C-bands } & \multicolumn{2}{|c|}{ Position of fluorochrome bands } \\
\hline & & & DAPI+ & $\mathrm{CMA}_{3}+$ \\
\hline \multirow[t]{10}{*}{1} & P. ledereri & most $p$ & $=\mathrm{C}$ & most; $11 / 13$ \\
\hline & P. aff. ledereri & most $p$ & $=C$ & most; \\
\hline & P. orbelicus & most & $=\mathrm{C}$ & most; \\
\hline & P. armeniacus TR-Balik lake & all $p$ & $=\mathrm{C}$ & all; $9 / 10$ \\
\hline & P. armeniacus TR-Camlibel pass & most $p$ & $=\mathrm{C}$ & most; $\mathbf{1 1 / 1 2}$ \\
\hline & P. ampliatus & $2 p+d, 3 p, 4 p, 9 / 10 p$ & $=\mathrm{C}$ & $2,9 / 10$ \\
\hline & P. pechevi & $2 / 3 d, 3 / 4 p, 5 p, 12 / 13 p$ & $=\mathrm{C}$ & $2 / 3,3 / 4,12 / 13$ \\
\hline & P. ebneri & $x i, 2 / 3 d, 3 / 4^{*} p, 2 / 13 p$ & most & $X \mathrm{i}, 2 / 3 \mathrm{~d}, 3 / 4^{*}, 12 / 13$ \\
\hline & P. Klisuriensis & most $p$ & $=C$ & 5,11 \\
\hline & P. marmaraensis & $2 / 3 d$, most $p$ & $=\mathrm{C}$ & most; \\
\hline 2 & P. cf. karakushi & most $p$ & $=\mathrm{C}$ & most; $11 / 13$ \\
\hline \multirow[t]{2}{*}{3} & P. cervus & most $p$ & $=\mathrm{C}$ & most; $\mathbf{3}, \mathbf{9}$ \\
\hline & P. bischoffi & all $p$ & $=\mathrm{C}$ & all \\
\hline 4 & P. chopardi & most $p$ & $=C$ & most; $\mathbf{5}, \mathbf{1 3}$ \\
\hline \multirow[t]{3}{*}{5} & P. brunneri & most $p$ & $=\mathrm{C}$ & most; $\mathbf{1 1 / 1 3}$ \\
\hline & P. macedonicus & most $p$ & $=\mathrm{C}$ & most; $13, \mathbf{X}$ \\
\hline & P. zwicki & $2 / 4 d, 5 d, 7 p, 9 / 10 d$ & 0 & $2,5,7,9$ \\
\hline \multirow[t]{2}{*}{6} & P. jonicus tessellatus & $1,2,3,12 / 13$ all i & $=\mathrm{C}$ & $1,2,3 ; 12 / 13$ \\
\hline & P. martinae & most $p$ & $=\mathrm{C}$ & most; $11 / 12$ \\
\hline \multirow[t]{2}{*}{7} & P. schmidtii & $3 / 4 p, 6 / 7 p$ & $=\mathrm{C}$ & $3 / 4,6 / 7$ \\
\hline & P. zonatus/varicornis & 0 & 0 & $4 / 5,10 / 13$ \\
\hline \multirow[t]{2}{*}{8} & P. ornatus & most $p$ & $=\mathrm{C}$ & most; $3 / 4,12 / 13$ \\
\hline & P. affinis & all $p$ & $=\mathrm{C}$ & all; 2, 5, 13 \\
\hline \multirow[t]{3}{*}{$?$} & P. ataturki & $12 / 13 p$ & 0 & $12 / 13$ \\
\hline & P. celebi & most $p$ & $=\mathrm{C}$ & most; $2 / 3,11 / 13$ \\
\hline & P. aff. glandifer & $1-5 p, 3 / 4 d^{*}$ & $1-5$ & $1-5, \mathbf{3 / 4}, \mathbf{1 0 / 1 2}$ \\
\hline \multirow[t]{2}{*}{1} & 1. hospodar & $3,10 / 12 p$ & $=\mathrm{C}$ & $3,10 / 12$ \\
\hline & 1. straubei ssp. & $2 / 3^{*} p, 6 p$ & 0 & $3 *, 6$ \\
\hline \multirow[t]{3}{*}{2} & I. nervosa & $3 / 4 p$ & $3 / 4$ & 3 \\
\hline & I. thracica & $2,12 / 13 p$ & most & most; 13 \\
\hline & 1. stenocauda obenbergeri & $3 / 4^{*} p, 10 / 11 p, 11 / 12^{*} p$ & $10 / 11,11 / 12$ & $11 / 12^{*}$ \\
\hline \multirow[t]{2}{*}{3} & 1. bureschi BG-Plana & $3,4,11 / 12,13 / 14$ & $=C$ & $11 / 12$ \\
\hline & I. yaraligozi & most $p$ & $=\mathrm{C}$ & $1^{*}, 3^{*}, 7^{*}, 11$ \\
\hline
\end{tabular}


Table 3 Heterochromatin patterns; localization of C-bands, DAPI and $\mathrm{CMA}_{3}$ signals in Poecilimon and Isophya species (Continued)

\begin{tabular}{|c|c|c|c|c|}
\hline \multirow[t]{2}{*}{4} & 1. taurica & $10 / 11,12 / 13^{*}$ & most & most; $12 / 13^{*}$ \\
\hline & I. brunneri & $3 i, 7 p, 9 p, 11 / 12 p$ & 0 & $7,9,11 / 12$ \\
\hline \multirow[t]{2}{*}{5} & I. modestior BG & $3 / 4^{*} p, 5 / 6 p, 12 / 13 p$ & $4 / 5,12 / 13$ & $3 / 4^{*}, 5 / 6$ \\
\hline & 1. modestior SR & $1 \mathrm{i} ; 2 / 3 p, 4 p, 9 p, 10 / 11 p$ & 0 & $1 / 2,3 / 4$ \\
\hline \multirow[t]{3}{*}{7} & Isophya sp. & most $p, 1 / 2^{*} p$ & $=\mathrm{C}$ & $1 / 2^{*}, 10 / 12$ \\
\hline & 1. zernovi & $3 / 4 p, 10 / 12 p$ & $=\mathrm{C}$ & $3,11 / 12$ \\
\hline & 1. autumnalis & 0 & 0 & $2 / 4,10 / 12$ \\
\hline 8 & I. schneideri & $3 p, 5 p, 11 p$ & $7 / 8$ & $3,5,11$ \\
\hline \multirow[t]{4}{*}{9} & 1. sureyai & $3 / 4 p, 11 / 12 p$ & $=\mathrm{C}$ & $3 / 4,11 / 12$ \\
\hline & 1. speciosa & $1 / 2 p, 3 / 4 p, 11 / 12 p, 13 / 14 p$ & 0 & $1 / 2,3 / 4$ \\
\hline & 1. amplipennis & $2 p, 5 / 6 p, 10 p$ & $5 / 6,10$ & $2,5 / 6,10$ \\
\hline & I. rizeensis & $2 / 3 p, 6 p, 7 / 8 p$ & $2 / 3$ & $3,6,7$ \\
\hline 10 & I. major & $1 / 2 p, 10 / 12 p, \times p$ & $1 / 2, x$ & $1 / 2,10 / 12, X$ \\
\hline
\end{tabular}

A slash between two numbers indicates imprecise identification of the chromosome pair (bivalent); $\mathrm{C}=\mathrm{C}$-bands; $0=\mathrm{DAPI}+$ signal not visualized; $\mathrm{p}=$ paracentromeric, $\mathrm{i}=$ interstitial, $\mathrm{d}=$ distal; $\mathrm{X}=$ sex chromosome; ${ }^{*}$ presence of polymorphism in homologous chromosomes; pairs of chromosomes with $\mathrm{CMA}_{3}+$ marked by bold typeface coincide with $18 \mathrm{~S}$ rDNA and NORs; TR=Turkey, BG = Bulgaria, SR=Serbia. The first column corresponds to that in Tables 1 and 2 .

complex, representing a few subspecies inhabiting a large area of secondary contact between possibly formerly isolated populations, where intrapopulation variation in the number of rDNA clusters is observed. This is usually connected with ongoing speciation and hybridization in zones of secondary contact [5,21,47].

According to our results analyzed in conjunction with known systematic and phylogenetic data transposition and recombination, or, alternatively, occasional loss of rDNA fragments clusters, may have often occurred multiple times in different lineages of Isophya and, rarely, in Poecilimon. Similar events resulting in a variable heterochromatin structure have been observed in other groups of Barbitistini, mostly taking place within or between taxa of recent origin [37].

\section{Conclusions}

The cytogenetic study presented herein constitutes the next step towards a better understanding of chromosomal organization and evolution within Phaneropterinae. We have outlined some general tendencies of chromosomal organization within Isophya and Poecilimon. These may result in unique species-specific characters or involve homoplastic changes in distinct lineages. And although chromosomal distribution of repeated DNA sequences could represent intrinsic aspects of the evolutionary dynamics of the repeated DNA families, our results have sometimes reflected inferences based on morphological, behavioral, and/or gene-sequence data. Thus, mapping of rDNA sequences and heterochromatin may in some cases be used as an additional marker for understanding relationships and routes of speciation within Barbitistini.

\section{Material and methods}

A total of 95 specimens of 39 Poecilimon species/subspecies and 112 specimens of 40 Isophya taxa (including 21 previously described species/subspecies [20]) were studied. Male adults and nymphs and female nymphs were collected from 2006 to 2012 in Eastern Europe and Turkey. Details of taxon names and their possible grouping and collection sites are given in Tables 1 and 2. Chromosome preparations were obtained from the gonads of last instar nymphs or adults. Testes and ovarioles were incubated in hypotonic solution ( $0.9 \%$ sodium citrate), fixed in modified Carnoy's solution - ethanol: acetic acid (3: 1), and stored at $2^{\circ} \mathrm{C}$ until use. Chromosome preparations for the examination of nucleolus organizer regions (NORs) and fluorescence in situ hybridization (FISH) experiments were made by tissue squashing using $45 \%$ acetic acid, subsequent removal of cover slips by the dry ice technique, and air-drying. The silver staining method $\left(\mathrm{AgNO}_{3}\right)$ for NOR location was performed according to the protocol by Warchałowska-Śliwa and Maryańska-Nadachowska [48]. Constitutive heterochromatin was revealed by the C-banding technique as described by Sumner [49]. In order to identify GC- and AT-rich regions, the preparations were stained with $\mathrm{CMA}_{3}$ and DAPI, respectively [50].

FISH with ribosomal 18S DNA (rDNA) genes and the telomeric sequence (TTAGG) ${ }_{n}$ was performed exactly as described in Warchałowska-Śliwa et al. [32]. Preparations were counterstained with DAPI (4,6-diamidino-2-phenylindole) and mounted in an anti-fade medium with DABCO. Images for FISH were captured using an AXIOSCOP 2 (Zeiss) microscope equipped with a CCD camera, filter set, and an ISIS5 image processing package (Metasystems $\mathrm{GmbH}$ ) at the Microscopic Centre of the Institute of 


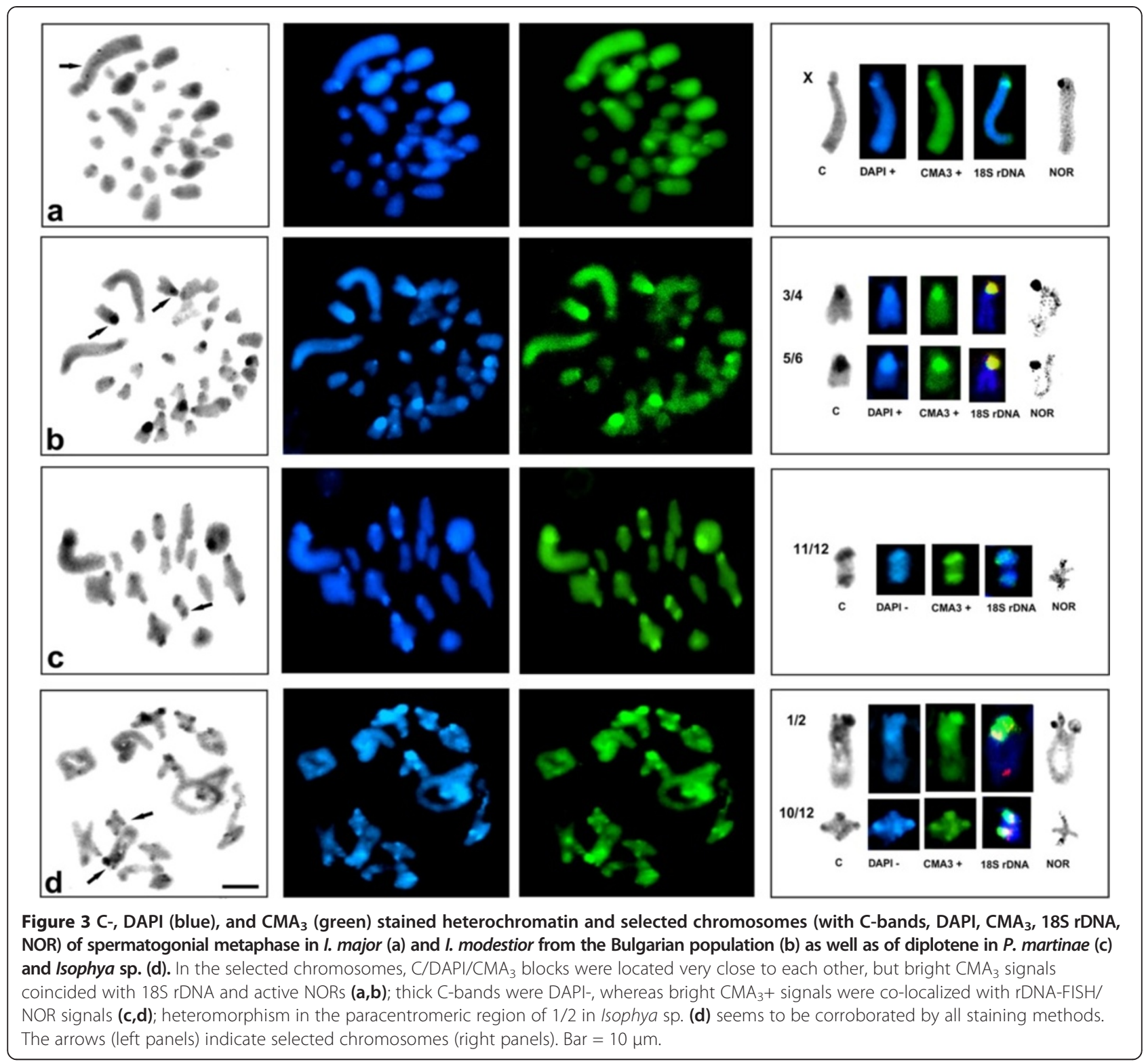

Cytology and Genetics, SB RAS, Novosibirsk, Russia. Slides with silver staining impregnation were examined under a Nikon Eclipse 400 light microscope fitted with a CCD DS-U1 camera and an NIS-Elements BR 3.0 image analyzing system (Nikon). At least 10 meiotic divisions (from diplotene to metaphase I) per male and at least three spermatogonial and/or oogonial metaphases (for some specimens) were analyzed using three techniques: $\mathrm{FISH}, \mathrm{AgNO}_{3}$ staining, and classical cytogenetic methods (C-banding and DAPI/ $\mathrm{CMA}_{3}$ staining). In each species, both the rDNA-FISH pattern and the location of active NORs were always recorded on meiotic bivalents in prophase $I$ in the same individuals.

\section{Abbreviations}

FISH: Fluorescence in situ hybridization; $\mathrm{CMA}_{3}$ : Chromomycin $\mathrm{A}_{3}$; DAPI: 4'6 diamidino-2- phenylindole; NOR: Nucleolar organizer region; tDNA-

FISH: Telomeric probe; rDNA: Ribosomal DNA; BG: Bulgaria; GR: Germany; MK: Macedonia; PL: Poland; RU: Russia; SR: Serbia; TR: Turkey; UA: Ukraine;

SL: Slovenia; a: acrocentric; sa: subacrocentric; sm: submetacentric; p: paracentromeric; d: distal; i: interstitial; i-d: interstitial near the distal end; C: C-bands; 0: DAPI + signal not visualized.

\section{Competing interests}

The authors declare that they have no competing interests.

\section{Authors' contributions}

BG, DPCH, EW-Ś made major contributions to conception and design of analyses, interpretation of data and writing the manuscript. AM-N, TVK, K-GH took part in data analysis. All authors interpreted the results, have read and approved the final manuscript. 


\section{Acknowledgements}

This research was supported by the Ministry of Science and Higher Education of Poland, grant N N303 611738 to E. Warchałowska-Śliwa, and by the research agreement between the Polish Academy of Sciences and Bulgarian Academy of Sciences (project coordinators E. Warchałowska-Śliwa and P. Michailova). Comparative studies of type specimens in the collections of the Naturkunde Museum (Berlin), Naturhistorisches Museum (Vienna), the Natural History Museum (London), and Hungarian Natural History Museum (Budapest) by D.P. Chobanov were financed by the SYNTHESYS (European Commission's Research Infrastructures Network funded under FP7) grants DE-TAF-3950, AT-TAF-546, GB-TAF-1320, HU-TAF-2202, respectively. T.V. Karamysheva was partially supported by the Mianowski Fund - Foundation for the Promotion of Science, Poland (2009) and RFBR, research project No. 14-04-00086 a. We owe special thanks to Battal Ciplak and Sarp Kaya (Akdeniz University, Antalya, Turkey) for their cooperation in the field studies in Turkey, to Sergey Ivanov (Taurida National University "V.I. Vernadsky", Simferopol, Ukraine) and Yuri Budashkin (Karadagh Nature Reserve, Ukraine) for their invaluable help in collecting samples in Crimea, and to Gerlind U.C. Lehmann and Arne W. Lehmann for collecting individuals in Slovenia. Thanks are due to two anonymous reviewers for their useful comments significantly improving the manuscript.

\section{Author details}

'Institute of Systematics and Evolution of Animals Polish Academy of Sciences, Sławkowska 17, Krakow 31-016, Poland. Institute of Biodiversity and Ecosystem Research, Bulgarian Academy of Sciences, Sofia, Bulgaria. ${ }^{3}$ Institute of Cytology and Genetics of the Siberian Branch of the Russian Academy of Sciences, Novosibirsk, Russia. ${ }^{4}$ Grillenstieg 18, Magdeburg 39120, Germany.

Received: 30 July 2013 Accepted: 24 February 2014

Published: 13 March 2014

\section{References}

1. Heller K-G: Evolution of song pattern in east Mediterranean Phaneropterinae: Constraints by the communication system. In The Tettigoniidae: biology, systematics and evolution. Edited by Bailey WJ, Rentz DCF. Bathurst (Crawford House Press) \& Berlin et al: Springer; 1990:130-151.

2. Eades DC, Otte D, Cigliano MM, Braun H: Orthoptera Species File Online; 2013. Version 2.0/4.1. Available from: http://Orthoptera.SpeciesFile.org/ (18.10.2013).

3. Boztepe Z, Kaya S, Çıplak B: Integrated systematics of the Poecilimon luschani species group (Orthoptera, Tettigoniidae): radiation as a chain of populations in a small heterogeneous area. Zool I Linnean Soc 2013, 169:43-69.

4. Çıplak B: Biogeography of Anatolia: the marker group Orthoptera. Mem Soc Entomol Ital 2004, 82(2):357-372.

5. Chobanov DP, Grzywacz B, lorgu I, Ciplak B, llieva M, Warchałowska-Śliwa E: Review of the Balkan Isophya (Orthoptera: Phaneropteridae) with particular emphasis on the Isophya modesta group and remarks on the systematics of the genus based on morphological and acoustic data. Zootaxa 2013, 3658:1-81.

6. Bey-Bienko GY: Orthoptera. In Sect. 2. Leaf bush-crickets (Phaneropterinae). Itth edition. Moscow - Leningrad: New Series 59. Fauna of the USSR. Zoological Institute of the Academy of Sciences of the USSR; 1954:385.

7. Can E: Zur Kenntnis von Isophya amplipennis Br. v. W., I. pavelii Br. v. W. und $I$. tenuicerca Rme. (Orth. Tettigoniidae), als Schädlinge von Eichenniederwäldern in Südosteuropa. I Zeitschrift für Angewandte Entomologie 1959, 43:387-411.

8. Ramme W: Beiträge zur Kenntnis der palaearktischen Orthopterenfauna (Tettig. et Acrid.). Mitt Zool Mus Berlin 1933, 18:416-434.

9. Ramme W: Zur Systematik, Faunistik und Biologie der Orthopteren von Südost-Europa und Vorderasien. Mitt Zool Mus Berlin 1951, 27:1-432.

10. Heller K-G: Zur Bioakustik und Phylogenie der Gattung Poecilimon (Orthoptera, Tettigoniidae, Phaneropterinae). Zool Jahrb Abt Anat Onot Tier 1984, 111:69-117.

11. Heller K-G: Bioakustik der europäischen Laubheuschrecken. Weikersheim: Josef Margraf; 1988:358.

12. Sevgili H, Çiplak B, Heller K-G, Demirsoy A: Morphology, bioacoustics and phylogeography of the Isophya major group (Orthoptera: Tettigoniidae:
Phaneropterinae): a species complex occurring in Anatolia and Cyprus. Eur J Entomol 2006, 103:657-671.

13. Heller K-G, Korsunovskaya OS, Sevgili H, Zhantiev RD: Bioacoustics and systematics of the Poecilimon heroicus-group (Orthoptera: Phaneropteridae: Barbitistinae). Eur J Entomol 2006, 103:853-865.

14. Heller K-G, Sevgili H, Reinhold K: A re-assessment of the Poecilimon syriacus group (Orthoptera 8. Tettigonioidea, Phaneropteridae) based on bioacoustics, morphology and molecular data. Insect Syst Evol 2008, 39:361-379.

15. Heller K-G, Willemse L, Odé B, Volleth M, Feist R, Reinhold K: Bioacoustics and systematics of the Poecilimon hamatus group (Tettigonioidea: Phaneropteridae: Poecilimon: Hamatopoecilimon n. subg.). J Orthopt Res 2011, 20:81-95.

16. Chobanov DP, Heller K-G: Revision of the Poecilimon ornatus group (Orthoptera: Phaneropteridae) with focus on Bulgaria and Macedonia. Eur J Entomol 2010, 107:647-672.

17. Kaya S, Ciplak B, Chobanov D, Heller K-G: Poecilimon bosphoricus group (Orthoptera, Phaneropterinae): iteration of morpho-taxonomy by song characteristics. Zootaxa 2012, 3225:1-71.

18. Warchałowska-Śliwa E, Heller K-G, Maryańska-Nadachowska A, Lehmann A: Chromosome evolution in the genus Poecilimon (Orthoptera, Tettigonioidea Phaneropteridae). Folia biol (Kraków) 2000, 48:127-136.

19. Warchałowska-Śliwa E, Chobanov DP, Grzywacz B, Maryańska-Nadachowska A: Taxonomy of the genus Isophya (Orthoptera, Phaneropteridae, Barbitistinae): Comparison of karyological and morphological data. Folia biol (Kraków) 2008, 56:227-241.

20. Grzywacz B, Maryańska-Nadachowska A, Chobanov DP, Karamysheva T, Warchałowska-Śliwa E: Comparative analysis of the location of rDNA in the Palaearctic bushcricket genus Isophya (Orthoptera: Tettigoniidae: Phaneropterinae). Eur J Entomol 2011, 108:509-517.

21. Grzywacz-Gibała B, Chobanov D, Warchałowska-Śliwa E: Preliminary phylogenetic analysis of the genus Isophya (Orthoptera: Phaneropteridae) based on molecular data. Zootaxa 2010, 2621:27-44.

22. Ullrich B, Reinhold K, Niehuis O, Misof B: Secondary structure and phylogenetic analysis of the internal transcribed spacers 1 and 2 of bush crickets (Orthoptera: Tettigoniidae: Barbitistini). J Zool Sys Evol Res 2010, 48(3):219-228.

23. Cabral-de-Mello DC, Oliveira SB, Moura RC, Martins C: Chromosomal organization of the $18 \mathrm{~S}$ and $5 \mathrm{~S}$ rRNAs and histone $\mathrm{H} 3$ genes in Scarabaeinae coleopterans: insights into the evolutionary dynamics of multigene families and heterochromatin. BMC Genetics 2011, 12:88.

24. Nguyen P, Sahara K, Yoshido A, Marec F: Evolutionary dynamics of rDNA clusters on chromosomes of moths and butterflies (Lepidoptera). Genetica 2010, 138:343-354.

25. Cabrero J, Camacho JPM: Location and expression of ribosomal RNA genes in grasshoppers: Abundance of silent and cryptic loci. Chromosome Res 2008, 16:595-607.

26. Loreto V, Cabrero J, López-León MD, Camacho JPM, Souza MJ: Comparative analysis of rDNA location in five Neotropical gomphocerinae grasshopper species. Genetica 2008, 132:95-101.

27. Cabrero J, López-León MD, Teruel M, Camacho JPM: Chromosome mapping of $\mathrm{H} 3$ and $\mathrm{H} 4$ histone gene clusters in 35 species of acridid grasshoppers. Chromosome Res 2009, 17:397-404.

28. Oliveira NL, Cabral-de-Mello DC, Rocha MF, Loreto V, Martins C, Moura RC: Chromosomal mapping of rDNAs and $\mathrm{H} 3$ histone sequences in grasshopper Rhammatocerus brasiliensis (Acrididae, Gomphocerinae): extensive chromosomal dispersion and co-localization of 5SrDNA/H3 histone clusters in the A complement and B chromosome. Mol Cytogenet 2011, 4:24.

29. Rocha MF, Melo NK, Souza MJ: Comparative cytogenetics analysis of two grasshopper species of the tribe Abracrini (Ommatolampinae, Acrididae). Genet Mol Biol 2011, 34:214-219.

30. Jetybayev IE, Bugrov AG, Karamysheva TV, Camacho JPM: Chromosomal localization of ribosomal and telomeric DNA provides new insights on the evolution of Gomphocerinae grasshoppers. Cytogenet Genome Res 2012, 138:36-45.

31. Warchałowska-Śliwa E, Maryańska-Nadachowska A, Heller K-G: Cytogenetic variability of the genus Saga Charp. (Orthoptera, Tettigoniidae, Saginae): heterochromatin differentiation. Caryologia 2007, 60:29-36.

32. Warchałowska-Śliwa E, Grzywacz B, Maryańska-Nadachowska A, Karamysheva TV, Rubtsov NB, Chobanov DP: Chromosomal differentiation 
among bisexual European species of Saga (Orthoptera: Tettigoniidae: Saginae) detected by both classical and molecular methods. Eur $J$ Entomol 2009, 106:1-9.

33. Warchałowska-Śliwa E, Grzywacz B, Maryańska-Nadachowska A, Karamysheva TV, Chobanov DP, Heller K-G: Cytogenetic variability among Bradyporinae species (Orthoptera: Tettigoniidae). Eur J Entomol 2013, 110(1):1-12

34. Hemp C, Heller K-G, Warchałowska-Śliwa E, Hemp A: A new genus and species of African Phaneropterinae (Orthoptera: Tettigoniidae), with data on its ecology, bioacoustics and chromosomes. Org Divers Evol 2010 10:215-226.

35. Hemp C, Heller K-G, Warchałowska-Śliwa E, Grzywacz B, Hemp A: Biogeography, ecology, acoustics and chromosomes of East African Eurycorypha Stål species (Orthoptera, Phaneropterinae) with the description of new species. Org Divers Evol 2013. DOl: 10.1007/s13127-012-0123-1.

36. Warchałowska-Śliwa E, Maryańska-Nadachowska A, Grzywacz B, Karamysheva T, Lehmann AW, Lehmann GUC, Heller K-G: Changes in the numbers of chromosomes and sex determination system in bushcrickets of the genus Odontura (Orthoptera: Tettigoniidae: Phaneropterinae). Eur J Entomol 2011, 108:183-195.

37. Warchałowska-Śliwa E, Grzywacz B, Maryańska-Nadachowska A, Karamysheva TV, Heller K-G, Lehmann AW, Lehmann GUC, Chobanov DP: Comparative physical mapping of the rDNA and heterochromatin in eight bushcricket genera of the tribe Barbitistini (Orthoptera: Tettigoniidae: Phaneropterinae). Genome 2013, 56(11):667-676

38. Messina A, Ippolito S, Lombardo F: Cariologia di alcune specie Europee di Phaneropterinae (Insecta, Orthoptera). Animalia 1975, 2:215-224.

39. Warchałowska-Śliwa E, Heller K-G: C-banding patterns of some species of Phaneropterinae (Orthoptera, Tettigoniidae) of Europe. Folia biol (Kraków) 1998, 46:177-181.

40. Warchałowska-Śliwa E: Karyotype characteristics of katydid orthopterans (Ensifera, Tettigoniidae) and remarks on their evolution at different taxonomic levels. Folia biol (Krakòw) 1998, 46:143-176.

41. Warchałowska-Śliwa E, Heller K-G, Maryańska-Nadachowska A: Cytogenetic variability of European Tettigoniidae (Orthoptera, Tettigoniidae): Karyotypes, C- and Ag-NOR-banding. Folia biol (Krakòw) 2005, 53:161-171.

42. Cabral-de-Mello DC, Martins C, Souza MJ, Moura RC: Cytogenetic mapping of $5 \mathrm{~S}$ and $18 \mathrm{~S}$ rRNAs and $\mathrm{H} 3$ histone genes in four ancient Proscopiidae grasshopper species: contribution to understanding the evolutionary dynamics of multigene families. Cytogenet. Genome. Res. 2011, 132:89-93.

43. Bressa MJ, Franco MJ, Toscani MA, Papeschi AG: Heterochromatin polymorphism in Holhymenia rubiginosa (Heteroptera: Coreidae) Eur J Entomol 2008, 105:65-72.

44. Schneider MC, Rosa SP, Almeida MC, Costa C, Cella DM: Chromosoma similarities and differences among four Neotropical Elateridae (Conoderini and Pyrophorini) and other related species, with comments on the NOR pattern in Coleoptera. J Zool Sys Evol Res 2007, 45:308-316.

45. Heller K-G, Lehmann A: Taxonomic revision of the European species of the Poecilimon ampliatus-group (Orthoptera Phaneropteridae). Mem Soc Entomol Ital 2004, 82:403-422.

46. Ünal M: Phaneropterinae (Orthoptera: Tettigoniidae) from Turkey and the Middle East II. T Am Entomol Soc 2010, 136:125-183.

47. Grzywacz B, Warchałowska-Śliwa E: Polymorphism of the genus Isophya (Orthoptera, Phaneropteridae, Barbitistinae) revealed by RAPD. Folia Biol (Krakòw) 2008, 56:153-157.

48. Warchałowska-Śliwa E, Maryańska-Nadachowska A: Karyotypes, C-bands, NORs location in spermatogenesis of Isophya brevipennis Brunner (Orthoptera: Phaneropteridae). Caryologia 1992, 45:83-89.

49. Sumner AT: A simple technique for demonstrating centromere heterochromatin. Exp Cell Res 1972, 75:304-306.

50. Schweizer D: Reverse fluorescent chromosome banding with chromomycin and DAPI. Chromosoma 1976, 58:307-324.

\section{doi:10.1186/1471-2148-14-48}

Cite this article as: Grzywacz et al:: A comparative study of genome organization and inferences for the systematics of two large bushcricket genera of the tribe Barbitistini (Orthoptera: Tettigoniidae: Phaneropterinae). BMC Evolutionary Biology 2014 14:48.

\section{Submit your next manuscript to BioMed Central and take full advantage of:}

- Convenient online submission

- Thorough peer review

- No space constraints or color figure charges

- Immediate publication on acceptance

- Inclusion in PubMed, CAS, Scopus and Google Scholar

- Research which is freely available for redistribution 